\title{
FAILURE ANALYSIS IN DEVELOPMENT \& MANUFACTURE FOR CUSTOMER
}

DOI: 10.12776/QIP.V17I2.203

\author{
DARINA JUHASZOVA
}

\section{INTRODUCTION}

Quality assurance of products and services is now an integral part of the automotive industry as well as of a wide range of other industries. An important part of quality management is a customer whose requirements for products and services influences and directs the running of the company.

An important part of the quality management system of the company is to establish procedures for quality planning. The sense of quality planning is in the prevention of either construction or manufacture failures, respectively their causes. Nevertheless it is a tool to increase the likelihood of early detection. FMEA method - analysis of possible failures and consequences (Failure Mode and Effects Analysis) is a most commonly used and customer required quality planning tool (Zgodavova, 1999). The complexity in the area of automotive industry is based in the manufacturing process as well as in the chain of suppliers the car producer must fully rely on (Zgodavova, 2009).

For car producer is important to have suppliers who can quickly and accurately respond to requests, quickly adapt to the rapid development and are reliable. Car producers require suppliers who have their processes under control, understand the specific requirements of their customers and focus on continuous improvement. This document focuses on the analysis of failures in the process of design, i.e. new product development which aim is to present such measures that are effective and implemented as a component of continuous quality improvement (Lengyel, et al., 2012). Risk FMEA analysis is used and deployed in the process of product design and enables to eliminate possible failures and reveal their possible causes in two basic stages: design and process. (Segismundo, et al., 2008; Carbone \& Tippett, 2004)

This article represents the methodology of FMEA application in the analysis of a new product design failures. In the case study is shown the use of few quality tools: Block Diagram or Matrix Analysis as tools for planning of implementation of FMEA. Furthermore the method of implementation of FMEA is proposed. 


\section{LITERARY SURVEY}

"Managing risk is not optional for organizations" (Reid, 2005). ISO 9004:2009 mentions risk only in general at the chapter 4.2 Sustained Success as meaning that "an organisation's environment is ever-changing and uncertain, and to achieve sustained success its top management should identify associated shortterm risks and deploy and overall strategy for the organisation to mitigate them" and it further refers to the standard ISO 31000:2009.

According to this standard risk is "the effect of uncertainty on objectives and effect is a positive or negative deviation from what is expected." Risk management refers to a coordinated set of activities and methods that is used to direct an organization and to control the many risks that can affect its ability to achieve objectives (ISO 31000:2009).

General Motors (GM) (Ford Motor Company, 2004:2) has defined FMEA as " $a$ systemized group of activities intended to:

- recognize and evaluate the potential failure of a product/process and its effects,

- identify actions which could eliminate or reduce the chance of the potential failure occurring, and

- document the process. It is complementary to the process of defining what a design or process must do to satisfy the customer".

Design Failure Mode and Effects Analysis (DFMEA) is used to uncover design risk, which includes possible failure, degradation of performance and potential hazards. The Design FMEA is typically the first FMEA tool used in product development. (Quality-One International, 2011)

Narayanagounder and Gurusami (2009, pp. 524) state that Failure mode and effects analysis (FMEA) is generally defined as a systematic process to identify potential design and process failures before they occur, with the intent of eliminating or minimizing the risks associated with them. It is know that the FMEA method was first reported in 1920, but its use is only strongly documented since the early 1960's. It was developed in the USA by National Aeronautics Space Agency (NASA). Since the beginning of 1970's the FMEA method has been used in the automotive industry to address serious quality problems caused by automobile manufacturers. When analysing by using FMEA, the system behaviour is evaluated for each potential failure mode of each system component. Where there are unacceptable effects of failure, design changes need to be applied to mitigate these effects. The failures for corrective actions are prioritized according to the criticality of the part. The corrective actions are based on the probability of the item's failure mode and on the severity of its effects. The parameters used in the RPN (Risk Priority Number) methodology to determine the criticality of an item failure mode are the severity, occurrence and 
detection. Severity is assessed according to the weightiness of the failure mode effect on the next level assembly, the system or the user. Occurrence is assessed according to the likelihood of failure, which represents the relative number of errors expected during the design life of the item. Detection ability is assessing the ability of the proposed verification program to identify potential design weaknesses before the part or assembly is released for production. The RPN is a mathematical calculation of the severity, the occurrence and the detection (in equation form: $\mathrm{RPN}=\mathrm{S} * \mathrm{O} * \mathrm{D}$ ). The RPN number is used to identify the most critical failure mode which leads to corrective action. The FMEA approach uses RPN to evaluate the risk. The most crucial disadvantage of the traditional FMEA approach is that different sets of Severity, Occurrence and Detection can produce identical value of RPN, but the risk of the consequences can be quite different. This could result in a waste of resources and time, or in some cases high risk events go unnoticed.

The following summary (Table 1) is prepared according to the literary research work of Narayanagounder and Gurusami (2009, pp. 525-526) and a number of approaches for prioritization of failure modes to overcome the shortcomings of the traditional RPN approach.

Table 1 - Literary research

\begin{tabular}{|c|c|c|}
\hline Author (year) & $\begin{array}{l}\text { Title method } \\
\text { for FMEA }\end{array}$ & Method description \\
\hline $\begin{array}{l}\text { John B. Bowles and C. } \\
\text { Enrique Peláez (1995, } \\
\text { cited in Narayanagounder } \\
\text { and Gurusami, 2009) }\end{array}$ & FMECA & $\begin{array}{l}\text { Method based on fuzzy logic for prioritization of } \\
\text { failures for corrective actions in a failure mode, } \\
\text { effects and criticality analysis }\end{array}$ \\
\hline $\begin{array}{l}\text { Rudiger Wirth et al. } \\
\text { (1996) }\end{array}$ & WIFA & $\begin{array}{l}\text { Knowledge-based FMEA to improve the process } \\
\text { and design FMEAs by knowledge-based support } \\
\text { of the user }\end{array}$ \\
\hline $\begin{array}{l}\text { Fiorenzo Franceschini } \\
\text { and Maurizio Galetto } \\
\text { (2001, cited in } \\
\text { Narayanagounder and } \\
\text { Gurusami, 2009) }\end{array}$ & FMEA & $\begin{array}{l}\text { Method able to deal with situations having } \\
\text { different importance levels for the three failure } \\
\text { mode component indexes: (Occurrence, Severity } \\
\text { and Detection) }\end{array}$ \\
\hline $\begin{array}{l}\text { Ravishankar and Prabhu } \\
\text { (2001, cited in } \\
\text { Narayanagounder and } \\
\text { Gurusami, 2009) }\end{array}$ & FMEA & $\begin{array}{l}\text { Modified approach for prioritizing failures in a } \\
\text { system FMEA to perform corrective actions using } \\
\text { ranks } 1 \text { through } 1000 \text { called risk priority ranks to } \\
\text { represent the increasing risk of the } 1,000 \text { possible } \\
\text { severity-occurrence-detection combinations }\end{array}$ \\
\hline $\begin{array}{l}\text { Anand Pillay and Jin } \\
\text { Wang (2003, cited in } \\
\text { Narayanagounder and } \\
\text { Gurusami, 2009) }\end{array}$ & FMEA & $\begin{array}{l}\text { New approach using 'fuzzy rule base' and 'grey } \\
\text { relation theory' to overcome some of the } \\
\text { drawbacks of traditional FMEA approach }\end{array}$ \\
\hline
\end{tabular}




\begin{tabular}{|c|c|c|}
\hline $\begin{array}{l}\text { Seung J. Rhee and } \\
\text { Kosuke Ishii (2003, cited } \\
\text { in Narayanagounder and } \\
\text { Gurusami, 2009) }\end{array}$ & $\begin{array}{l}\text { Life Cost- } \\
\text { Based FMEA }\end{array}$ & $\begin{array}{l}\text { Methodology, which measures the failure or risk } \\
\text { in terms of cost. A Monte Carlo simulation is } \\
\text { applied to perform a sensitivity analysis on the } \\
\text { variables associated to failure cost: occurrence, } \\
\text { detection time, fixing time, and delay time }\end{array}$ \\
\hline $\begin{array}{l}\text { Seyed-Hosseini et al. } \\
\text { (2006, cited in } \\
\text { Narayanagounder and } \\
\text { Gurusami, 2009) }\end{array}$ & DEMATEL & $\begin{array}{l}\text { Method called Decision Making Trial and } \\
\text { Evaluation Laboratory approach for } \\
\text { reprioritization of failure modes in a system } \\
\text { FMEA for actions, which prioritizes alternatives } \\
\text { based on severity of effect or influence and direct } \\
\text { and indirect relationships between them }\end{array}$ \\
\hline $\begin{array}{l}\text { Arunachalam and } \\
\text { Jegadheesan }(2006 \text {, cited } \\
\text { in Narayanagounder and } \\
\text { Gurusami, 2009) }\end{array}$ & FMEA & $\begin{array}{l}\text { Modified FMEA with a reliability and cost-based } \\
\text { approach to overcome the current drawbacks of } \\
\text { the conventional FMEA }\end{array}$ \\
\hline $\begin{array}{l}\text { Chensong Dong (2007, } \\
\text { cited in Narayanagounder } \\
\text { and Gurusami, 2009) }\end{array}$ & FMEA & $\begin{array}{l}\text { Cost effective failure mode and effects analysis } \\
\text { tool to overcome the disadvantages of the } \\
\text { traditional FMEA wherein the cost due to failure } \\
\text { is not defined }\end{array}$ \\
\hline $\begin{array}{l}\text { Jih Kuang Chen (2007, } \\
\text { cited in Narayanagounder } \\
\text { and Gurusami, 2009) }\end{array}$ & ISM & $\begin{array}{l}\text { Interpretive structural model to evaluate the } \\
\text { structure of hierarchy and interdepen,dence of } \\
\text { corrective action and the analytic network process } \\
\text { to calculate the weight of a corrective action and a } \\
\text { utility priority number (UPN) to combine the } \\
\text { utility of corrective actions and make a decision } \\
\text { on improvement priority order of FMEA }\end{array}$ \\
\hline $\begin{array}{l}\text { Carbone and Tipett } \\
\text { (2004) }\end{array}$ & RFMEA & $\begin{array}{l}\text { Modification of the process, product, and service } \\
\text { FMEA technique. The detection value of the } \\
\text { standard FMEA is modified for use in the project } \\
\text { environment }\end{array}$ \\
\hline $\begin{array}{l}\text { Lian Yu Zheng et al. } \\
\text { (2002) }\end{array}$ & FMEA & $\begin{array}{l}\text { Knowledge-enriched model for process FMEA } \\
\text { represents the process FMEA knowledge by } \\
\text { algorithm to calculate the similarity among } \\
\text { process failure problems based on "concept } \\
\text { distance" }\end{array}$ \\
\hline $\begin{array}{l}\text { Estorilio and Posso } \\
\text { (2010) }\end{array}$ & Process FMEA & $\begin{array}{l}\text { Application strategy for automotive companies to } \\
\text { correct problems associated with the use of } \\
\text { FMEAs }\end{array}$ \\
\hline $\begin{array}{l}\text { Shirouyehzad et al. } \\
\text { (2011) }\end{array}$ & FMEA & $\begin{array}{l}\text { FMEA approach to identify critical failure factors } \\
\text { in ERP (Enterprise Resource Planning) } \\
\text { implementation }\end{array}$ \\
\hline
\end{tabular}

It is important to mention, that the new techniques in the prioritization of failures in the literature does not remove some of the disadvantages in the traditional FMEA approaches. 


\section{METHODOLOGY}

Recent research in the literature (Pira, 2002; Zgodavová, et al., 2002; Tosenovsky \& Tosenovsky, 2012) shows that a distinction is made in the system FMEA, FMEA of a product (construction) and FMEA of a process (process). The FMEA is a team analysis of possibilities of failures in the considered design, the risk assessment and the design and the implementation of measures leading to an improvement of the quality (Česká společnost pro jakost, 1997). This article describes a method that takes into account the presented aspects and also a procedure in which the quality tools are used. The first used tool is Block Diagram. It is a graphic description of relations between the product, its environment and its components. The role of the Block Diagram is to depict the analysed structure. The drawn line indicates where the analysis of the product ends. During a brainstorming session (creative problem solving method based on group solution) relevant data and facts are collected from all technical departments and persons respectively. who are part of a specific project (new product design) and are recorded to the Block Diagram. This ensures a unified understanding of the product within the team and allows a clear view of the product and its relation to its environment. The Block Diagram (Figure 1) contains following components:

- Analysed product name;

- Product environment (surrounding);

- Description of the physical relation to adjacent parts;

- Inputs and outputs;

- Boundaries of responsibility for the product system;

- Product components $\left(1^{\text {st }}\right.$ level $)$;

- Specific requirements / functions / features.

It is important to notice that the Block Diagram does not have a prescribed form. It can be drawn freehand or converted into a graphic form. It is a living document that throughout the design phase of the product may change. The relations to its environment or individual components can vary, can be added or deleted in various stages of development according to customer specific requirements or changing design solutions.

The Block Diagram is the basis for creating a Matrix Analysis. Product components listed in the Block Diagram and specific requirements or functions create its core. The sense of Matrix Analysis is to specify priorities and link functions of the analysed product with its components. 


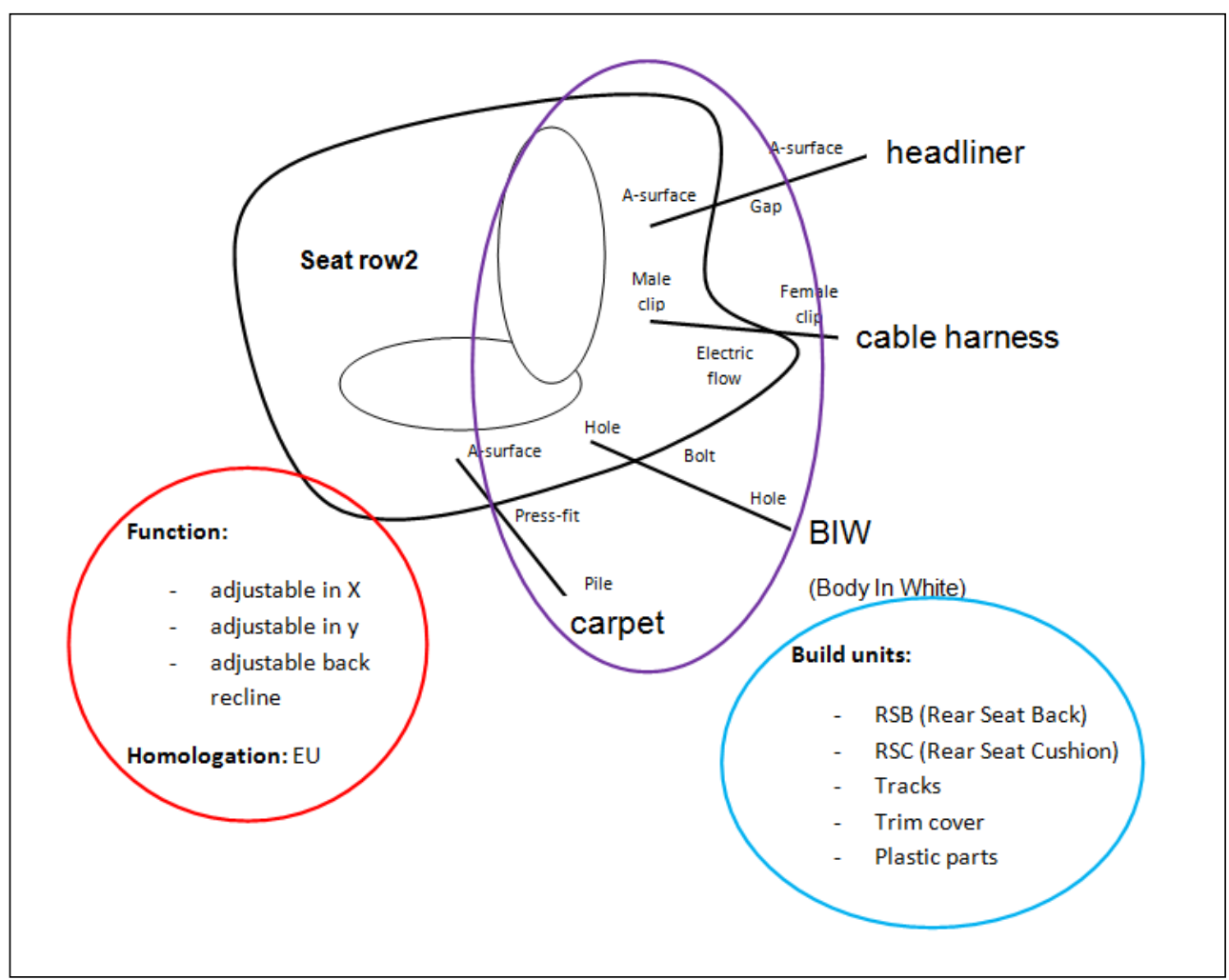

Figure 1 - Block diagram and information crossing to the Matrix analysis (author's own handling)

Components of the product are listed from the left in the first column of the Matrix Analysis and product functions are presented within the first top line. In the upper left corner is always presented the name of the analysed product. (Figure 4). All functions must be assigned to one of the six basic functions of Matrix Analysis:

- Safety \& Legal (9),

- Main functions (9),

- Packaging (3),

- Craftsmanship \& Comfort (3),

- Manufacturability (3),

- Serviceability (1).

Numbers in brackets represent the weight of each function.

When the individual product functions were assigned to the functions of Matrix Analysis it is possible to start with risk assessment. This includes the assessment, the analysis and assigning weights to show the effect of each component on the 
ability to provide product function. In this case weight values are 1,3 , and 5 . The value 5 means a significant effect on the product function. If a component fails the product function fully fails. If the component has a modest but still significant effect on the product function the assigned value is 3 . If the component has a negligible or minor effect on product function the assigned value is 1 . In case of no impact the field remains empty. The fields with assigned value 1 or 0 are not considered in the FMEA.

Example for assigning weights to the components of the functionality of the product is shown in Figure 2. Presented is the back of the car seat consisting of a metal structure, foam and fabric cover. It expresses the effect of the individual components of the seat (metal structure, foam, trim cover) on the function "Aesthetic fulfilment of requirements for the width of the back".

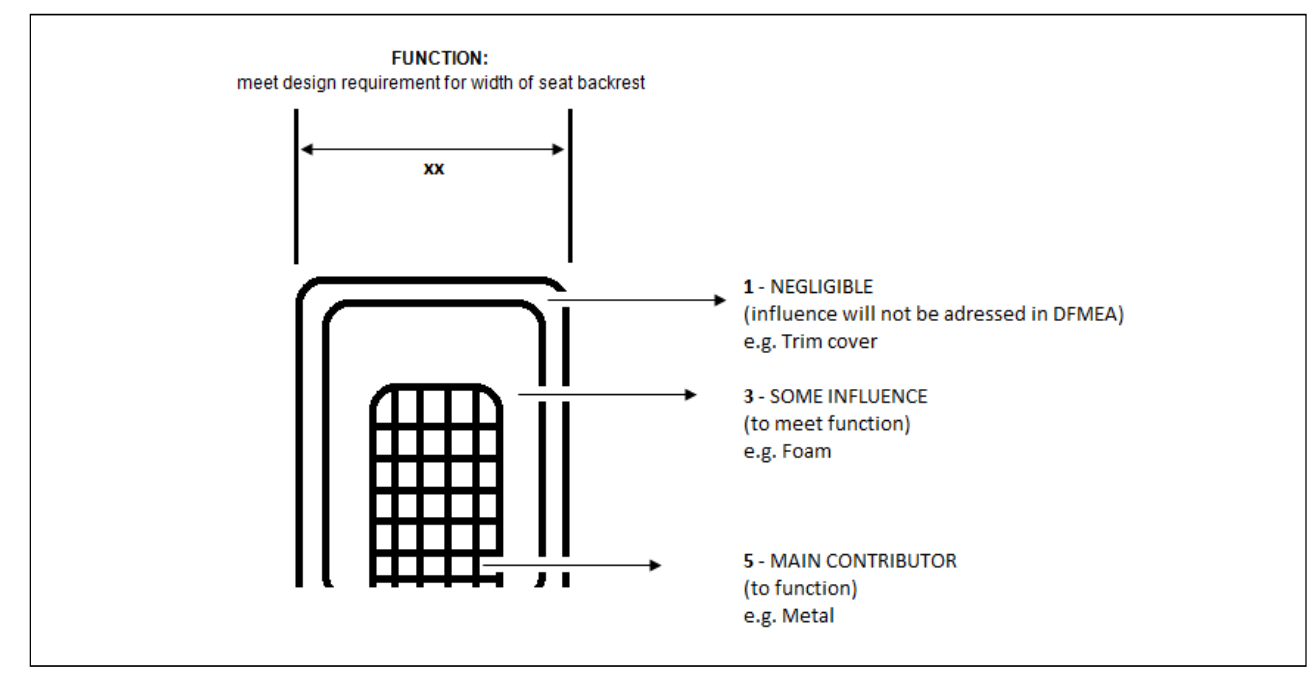

Figure 2 - Assign weights of product components to the functions (author's own handling)

The solved Matrix Analysis (see Figure 4) forms the basis for further analysis, which is D-FMEA. D-FMEA risk analysis is a systematic process for identifying potential design and process failures before they occur to eliminate or minimize the risk associated with them. An important part of the analysis is to set priorities of potential failures and set corrective actions to reduce the final risk number (RPN - Risk Priority Number). The value of Severity is in the range of 1-10. Severity, probability of Occurrence and probability of Detection form the RPN value which is decisive in the analysis. 
Through D-FMEA we are able:

- to identify potential failures, causes and effects,

- to determine the risk (Severity, Occurrence, Detection),

- to define and prioritize actions, name those responsible for the actions, and create deadlines,

- identify special characteristics as a result of the analysis,

- to initiate action,

- to achieve continuous documentation,

- to document expert knowledge,

in order to reduce potential product weaknesses to a minimum.

\subsection{Case study}

The aim of this case study is to show at a particular example the possibilities of using the Block Diagram and Matrix Analysis during the implementation planning of FMEA Johnson Controls Inc., s.r.o. - OZ Trencin.

Step 1: The Block Diagram begins by defining the product, the environment and the relations of which are further analysed. It is important that on the brainstorming session attend all responsible persons in the field of Product Design, Manufacturing and Quality to ensure a flow of needed information and include all relevant relations of product.

1.1 Product selection for the analysis: fabric cover for front seat is analysed. Customer is a multi-purpose and off-road vehicles manufacturer Land Rover. Seat covers are in following variants: leather, fabric and their combination. A total sum of 8 variants.

1.2 Product environment overview: during the brainstorming session team members nominate the environment of the product. The environment includes all the elements which can come into contact with the cover. These elements are entered in the Block Diagram (blue cells, Figure 3).

1.3 Mapping inputs, outputs and relations: inputs, outputs and product relations with its environment are assigned. An example is the relation of the cover to the metal structure of the seat (backrest and seat). There are present handles on the cover (retainers) and small hooks on the metal seat structure. The relation between them is hooking (hold). The handles on the cover are considered as the inputs and hooks on the structure as the outputs (white cells, Figure 3).

1.4 Definition of responsibility boundaries: the boundary line determines where the product analysis ends. It's important to clearly determine where the responsibility for the product on the supplier side extends and for what exactly the customer is responsible. 
1.5 Specific product features: all functions that particular product of a specific customer contains in addition to its basic functions. For example soft airbag module, seat heating, seat belt reminder sensor etc.

1.6 Product components: all components of which the product is manufactured and are transferred to the Matrix Analysis. Following parts are presented for the analysed product: Trim cushion cover; Trim back cover.

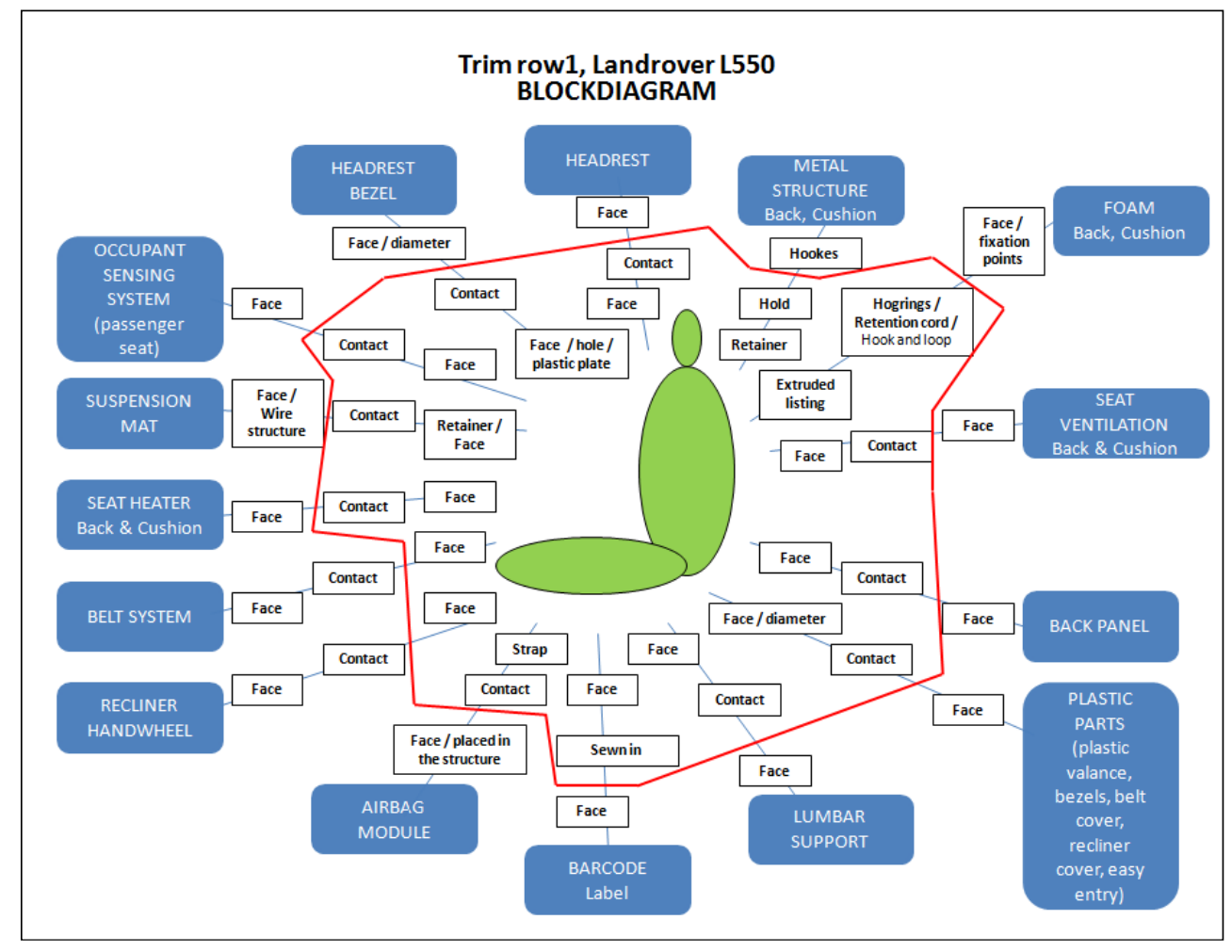

Figure 3 - Product, its surrounding, relationships and responsibility boundaries (author's own handling)

Step 2: Block Diagram is used as a basis for processing of Matrix Analysis.

2.1 Entering of the components of the product and its functions: in the first column from the left are input product components (see section 1.6). Along the line of the table are entered all the product functions. Product functions are those that shall be further analyzed in the DFMEA. These functions include all special functions of the cover (see section 1.5) as seat heating or lumbar support and others. 
2.2 Assigning of functions to the basic categories of D-FMEA and assigning of their weights: each function of the cover is assigned to the basic categories of the D-FMEA: Safety \& Legal requirements; Main functions; Packaging; Craftsmanship \& Comfort; Manufacturability; Serviceability. In the same time the functions are assigned to their weights: ranking of 9 for Safety \& Legal and Main functions; ranking of 3 for Packaging, Craftsmanship \& Comfort and Manufacturability; ranking of 1 for Serviceability.

2.3 Assigning of weights to the relation between product component and its function: they are assigned by mutual agreement in a team within range of 1, 3 and 5. Ranking of 5 is the maximum weight or the most significant effect of the component to the function. Weight 3 means moderate and weight 1 negligible effect. Fields that are left blank indicate that component has no effect to the function.

2.4 Prioritization: based on a prepared Matrix Analysis is possible to decide which component or which function of the cover should be analyzed in the D-FMEA as a priority. As long as we select a component the highest weight has the Trim back cover row1 (289). If we decide to analyze as a priority a function the highest weight (90) is in the category Safety \& Legal.

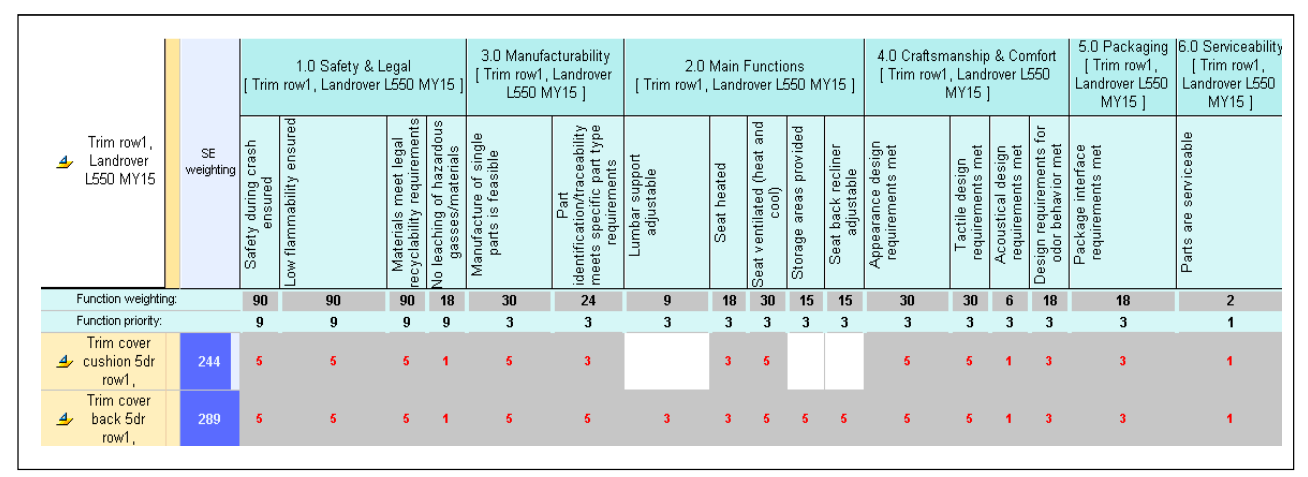

Figure 4 - Matrix analysis (author's own handling in SCIO software, Plato, 2013)

Step 3: D-FMEA Realization. This particular D-FMEA is treated as FMEA with the proposed actions and responsibilities which has the appearance of the classical form used in the implementation of FMEA. In the analysis the severity, occurrence and detection of specific potential failure is evaluated. If there is an unacceptable risk it is necessary to implement a change or corrective action. Corrective action can be preventive (e.g. numerical calculations) or detective (e.g. tests performed during the development phase). Based on the positive 
results it is possible to lower the risk number (RPN) while the value of severity never changes. The conditions for implementing corrective actions are following:

- $\quad \mathrm{RPN}>100$

- Severity $>7$

- Occurrence $>5$

- Detection $>5$

\section{CONCLUSION}

FMEA is an advanced tool that can be defined as simple and intuitive providing added value to the risk management process. It presents the concept of a simple risk assessment based on probabilities and consequences by adding occurrence and detection attributes of risk event. D-FMEA is based on an risk assessment and also RPN which requires an immediate response plan. When the D-FMEA is properly used it can reduce the project risk and serve as a source of information for future projects so-called lessons learned.

The use of the Block Diagram and Matrix Analysis is useful during the implementation of FMEA, in the process of developing a new product:

- Using the Block Diagram can be determined the environment of the product, its relations with the environment, inputs and outputs, the boundaries of responsibilities, special functions and components. It provides a common understanding within the product team.

- The Matrix Analysis allows expressing the effect of analysed product component to provided functions. It also provides the ability to determine which components or product functions is in D-FMEA addressed as a priority.

Both tools are useful for product development. From the point of view and aspects that become apparent from the shown examples Block Diagram and Matrix Analysis can be used as a key factors to handle and develop the proposed FMEA methodology which are contribute to the improvement of product development process in the automotive industry. It is also the cornerstone for the implementation of the proposed FMEA methodology and also of D-FMEA and P-FMEA.

FMEA methodology eliminates the possibility of failures that could lead to the need of technical changes on the product and thereby endanger the smooth startup of new production. Case study on a particular example shows the use, implementation and benefits of the proposed FMEA methodology. 


\section{ACKNOWLEDGEMENT}

This way I want to thank to my tutor prof. Ing. Kristina Zgodavova, PhD. This article is handled as part of KEGA 009TnUAD-4/2011 Creative Laboratory Engineering Education at Technical Faculties „CRELABTE“ supported by Ministry of Education, Science, Research and Sport of the Slovak Republic.

\section{REFERENCES}

British Standard Institution, 2009. BS EN ISO 9004:2009 Managing for the sustained success of an organization. A quality management approach. London: BSI.

British Standard Institution, 2010. BS ISO 31000:2009 Risk management. Principles and guidelines. London: BSI.

Carbone, T. A., Tippett, D. D., 2004. Project risk management using the project risk FMEA. Engineering Management Journal, [online] Available at: <http://fmeainfocentre.com/updates/may2011/Project\%20Risk\%20Management $\%$ 20Using\%20the\%20Project\%20Risk\%20FMEA.pdf> [Accessed 14 April 2013].

Česká společnost pro jakost, 1997. VDA 4.2 Zabezpečování jakosti před sériovou výrobou: systémová FMEA. Praha: CSJ.

Estorilio, C., Posso, R. K., 2010. The reduction of irregularities in the use of "process FMEA". International Journal of Quality \& Reliability Management, [e-journal] 27. Available through: Emerald Group Publishing website <http://www.emeraldinsight.com/search.htm?st1=FMEA\&ct=all\&ec=1\&bf=1 >

[Accessed 15 December 2012].

Ford Motor Company, 2004. Failure Mode and Effects Analysis, FMEA Handbook (with Robustness Linkages), FMEA Handbook Version 4.1, Dearborn, MI.

Lengyel, L., Zgodavova, K., Bober, P., 2012. Modeling and Simulation of Relocation of a Production in SIMPRO-Q Web Based Educational Environment. International Journal of Advanced Corporate Learning, [e-journal] 5(1), pp. 26-31. Available through: International Journal of Advanced Corporate Learning, website <http://online-journals.org/i-jac/article/view/1878> [Accessed 21 April 2013].

Narayanagounder, S., Gurusami, K., 2009. A new approach for prioritization of failure modes in design FMEA using Anova. World Academy of Science, Engineering and Technology, International Science Index 25, 3(1), pp. 485 - 493. Available at: <http://www.waset.org/journals/waset/v25/v25-96.pdf> [Accessed 14 April 2013]. 
Pentti, H., Atte, H., 2002. Failure Mode and Effect Analysis of Software - based Automation Systems. [online] Available at: <http://www.stuk.fi/julkaisut/tr/stukyto-tr190.pdf> [Accessed 14 April 2013].

Pira, R., 2002. Niektoré poznatky z aplikácie metódy FMEA v automobilovej výrobe. Q-magazín, Záŕí 2002 [pdf]. Available at:

<http://katedry.fmmi.vsb.cz/639/qmag/mj29-cz.htm> [Accessed 14 April 2013].

Plato AG, 2013. Scio FMEA (5.1). [computer program] Plato AG. Available at: < http://www.plato.de/home-en.html> [Accessed 07 April 2013]

Quality-One International, 2011. Quality \& Reliability Product and Process Development, FMEA. [online] Available at: 〈http://quality-one.com/fmea/> [Accessed 14 April 2013].

Reid, R. D., 2005. "FMEA-Something Old, Something New", Quality Progress, May, 2005, p. 90.

Segismundo, A., Cauchick Miguel, P.A., 2008. Risk management in $e$ development of new products. A review and classification of the literature. Product: Management \& Development, [online] Available at: $<$ http://pmd.hostcentral.com.br/revistas/vol_06/nr_1/v6n1a06.pdf > [Accessed 21 April 2013].

Shirouyehzad, H., Dabestani, R., Badakhshian, M., 2011. The FMEA Approach to Identification of Critical Failure Factors in ERP Implementation. [pdf] Canadian Center of Science and Education. Available at: <http://www.ccsenet.org/journal/index.php/ibr/article/view/9439/7842>

[Accessed 15 December 2013].

Tosenovský J., Tosenovsky, F., 2012. Possibilities of Production Process Financial Assessment. Proceedings of the Conference Financial management of firms and financial institutions, Ostrava, November 9. - 10., 2013.

Wirth, R., B. Bernd, Kramer, A., Peter, G., 1996. Knowledge-based Support of System Analysis for the Analysis of Failure Modes and Effects. Journal of Artificial Intelligent, 9(3), pp. 219-229.

Zgodavová, K., 1999. FMEA procesov riadenia kvality. Kvalita Inovácia Prosperita, [online] Available at: <http://qip-journal.eu/files/1999/12/zgodavova_1-2-99.htm>[Accessed 21 April 2013].

Zgodavová, K., Linczenyi, A., Novaková, R. Slimak, I., 2002. Profesionál kvality / Quality for Professionals. Košice: Technical University of Košice.

Zgodavová, K., Majerik, M., 2009. Mechatronic product proportionality and inter-changeability management: mechanical components. Annals of DAAAM \& Proceedings, [e-journal]. Abstract only. Available through: EBSCO website <http://connection.ebscohost.com/c/articles/55674590/mechatronic-productinterchangeability-management-electronic-components> [Accessed 21 April 2013]. 
Zheng, L. Y., Chin, S. K., Wei, L., 2002. Knowledge-enriched Process FMEA Model For Process Planning. Asian Journal on Quality, [e-journal] 3(1). Available through: Emerald Group Publishing website $\langle$ http://www.emeraldinsight.com/search.htm?st1=FMEA\&ct=all\&ec=1\&bf=1> [Accessed 15 December 2012].

\section{ABOUT THE AUTHOR}

Ing. Darina Juhaszova, Johnson Controls Inc., s.r.o. - OZ Trencin, external Ph.D. student, Technical University of Kosice, Faculty of Metallurgy, Department of Integrated Management, Park Komenskeho 3, 040 01, Kosice, Slovakia, e-mail: juhaszova.darina@gmail.com. 